\title{
Detailed Literature Review: Antecedents Affecting the Flight Risk or Turnover Intention of Professionals
}

\author{
Archana Singh*
}

\begin{abstract}
Employee turnover has attracted significant research worldwide because of the high cost it entails. These costs include recruitment, selection, training, adjustment time, possible product, and/or service quality problems which often exceed hundred percent of the annual salary for the position being filled. Understanding the factors that influence the turnover gives organisations the opportunity to reduce selection and training costs, increase employee morale and customer satisfaction and enhance organisational productivity. This paper traces the work done by researchers in understanding the flight risk or Turnover Intention behaviour of professionals and thus helps understand and curtail turnover thereby curtail costs for organisations.
\end{abstract}

Keywords: Flight Risk, Professionals, Antecedents, Turnover, Turnover Intention, India

\section{Introduction}

Research is being conducted in the area of employee turnover in different countries, including India, China, Europe, Australia, Israel, Pakistan and Africa but most work in this field is done in the U.S. The research studies cover various perspectives: psychological (attitudinal-individual organisational), sociological and economic.

\footnotetext{
CHRIST (Deemed to be University), Bangalore, India; archana.singh@christuniversity.in
} 
These studies cover entrepreneurial, large and medium organisations as well as several industries and sectors. Researchers have proposed models explaining the theory and empirical studies and have tested these models. Finally, the review has focussed more on the studies that deal with the turnover of professionals.

\subsection{Major streams of research in turnover}

There are two major streams of research in the field of employee turnover behaviour: "Traditional Stream" and "Job Embeddedness Stream." The traditional stream of research tries to find the answer to the question, 'Why people quit?'

The job embeddedness research stream explains and answers the question, 'Why people stay?' It explores factors related to the job in the organisational environment, family, and community. It is also referred to as the intent to stay or behavioural attachment (Halaby, 1986; Mueller et al., 1999).

Thus, the main purpose of both the streams of research is to understand the antecedents of turnover to predict the probable turnover rate so that organisations can plan and implement strategies, policies, plans and procedures to enhance the retention of their human capital.

Longitudinal research carries this forward to correlate the actual turnover rate with turnover intentions. Significant questions however, remain partially answered: Why do some employees, under similar organisational environment self-construct a poor relationship with the organisation while others self-construct a rewarding relationship and continue to stay? Also, why do employees with high-performance records, high rewards and growth opportunities still choose to leave? In this context, the role of human-resource practices acquires critical importance. Various studies have looked at Psychological, Sociological and Economic perspective to understand turnover.

Turnover has most often been examined as the consequence of an individual decision process with the individual acting in isolation Pfeiffer (1991). Virtually, all the dominant models of turnover conceptualise it as an individual decision without considering the effect of social structures. It is, therefore, not an easy task to review 
the literatures of intensive continuous research done over a period of sixty years, when by 1980 more than 1500 papers had been presented on employee turnover and retention based on the psychological perspective alone (Muchinsky \& Morrow, 1980).

\subsection{Turnover rate}

Turnover rate has been defined by Price (1977) as the ratio of the total number of employees who have left divided by the average number of employees in that organisation during the same period. Mobley (1982) has defined employee turnover as the termination of material income from the organisation. This concept by Mobley has now become the basis for many organisational studies (Abelson, 1984; McEvoy, 1985; Cotton et al., 1986). It is a voluntary turnover when employees leave on their own. This kind of voluntary turnover is considered dysfunctional. This study does not deal with involuntary turnover.

\subsection{Turnover intention or flight risk}

The behaviour that precedes turnover is defined as turnover intention. Firth, Mellor, Moor and Loquet (2004) define it as the individual thinking about quitting a job. An individual who nurtures the thought of quitting his present job is more likely to do so if the right conditions exist or if adverse conditions that triggered the thought of intent persist (Ajzen \& Fishbein, 1980).

Shore and Martin (1989) found that the relationship between intention which is flight risk and the actual turnover was quite strong. As the data about actual voluntary turnover is not often available or, not correctly provided by organisations, the conception often used is the turnover intent. It is the job-hunting behaviour of individuals that facilitate the process of receiving job opportunities. Turnover intent or flight risk is a dependent variable of numerous studies that have studied antecedents that influence the turnover (Allen, 1999, Price, 1977).

There are three reasons to study turnover intentions or flight risk instead of actual the turnover (Thompson \& Terpening, 1983). First, there is time lapse between the measurement of 'an employee given reason for leaving' and 'actual turnover' and this results in measurement unreliability. Records of exit surveys were not 
maintained to give accurate reasons of why employees actually left. Second, the use of archival data did not always specify why employees left their employer. Third, the real reasons for leaving may not have been given by employees in order to protect privacy. Therefore, the intention to quit or flight risk is considered as the best predictor of turnover (Igbaria \& Greenhaus, 1992).

\subsection{Antecedents of turnover intentions / flight risk}

Numerous studies have been conducted to determine the specific drivers of turnover, examining issues related to the work environment, job design, the external environment, individual demographics, job performance, the withdrawal process, and so on. A comprehensive meta-research presents the relative importance of a wide variety of turnover predictors (Bauer, Bodner, Erdogen, Truxillo \& Tucker, 2007; Greiffeth et al., 2000; Phillips, 1998). The positive values indicate that as the predictor increases the likelihood of turnover increases; a negative value indicates that as the predictor increases the likelihood of turnover decreases. These estimates represent summaries and some relationships may differ depending on each unique context and setting. There are implications that generally apply across settings (Allen, Bryant \& Verdman, 2010). 
Exhibit 2.1 Meta-Analysis of Turnover (Source: Allen, Bryant, \& Verdman,2010).

\section{Meta Analytic relationship with Turnover}

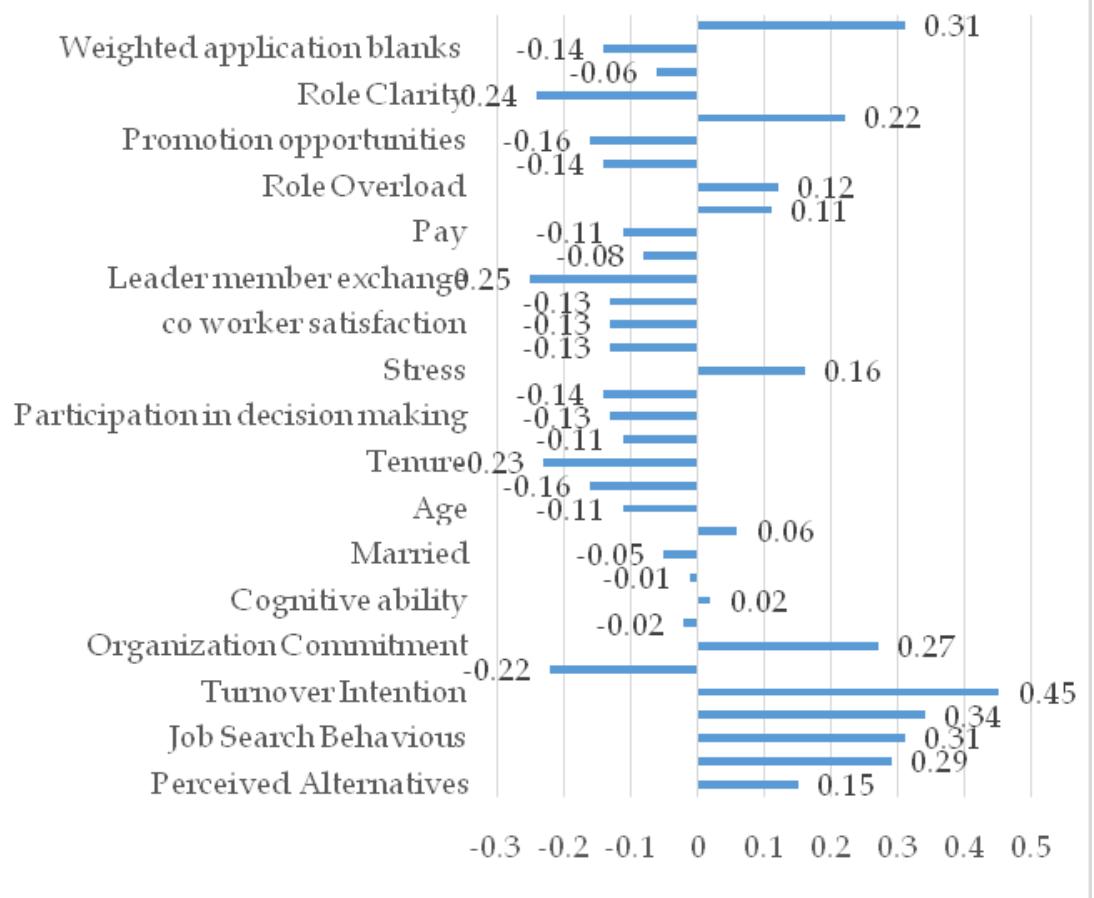

At the organisational level, effective HRM practices not only increase the performance but also decrease employee turnover (Arthur, 1994; Huselid, 1995; Lepak \& Snell, 2002).

Meta-research by Griffeth, Hom and Gaertner (2000), on employee voluntary turnover has reviewed all major research prior to the year 2000, including updating their earlier similar study (1995) and also one done by Cotton and Tuttle (1986). It presents a wideranging quantitative review of the predictive strength of all turnover antecedents estimating variability of predictor-quit relationships as well as their statistical reliability. It also identifies various moderators of antecedents-turnover correlations. Since it provides baseline data about all the antecedents, the contents of the important tables need to be discussed in the review. 
Table 2.1 Predictors Correlation with Turnover Intentions

\begin{tabular}{|c|c|c|}
\hline Predictors & $\begin{array}{l}\text { Av. weighted correlation for } \\
\text { measurement error in the } \\
\text { predictors }\end{array}$ & $\begin{array}{l}\text { Q-Static test for } \\
\text { moderators }\end{array}$ \\
\hline Overall job satisfaction & -.19 & 231.27 \\
\hline Met expectations & -.13 & 17.64 \\
\hline \multicolumn{3}{|l|}{ Compensation factors } \\
\hline Pay & -.09 & 287.69 \\
\hline Pay satisfaction & -.06 & 39.50 \\
\hline Distributive justice & -.07 & 20.62 \\
\hline \multicolumn{3}{|l|}{ Leadership } \\
\hline Supervisory satisfaction & -.010 & 18.38 \\
\hline $\begin{array}{l}\text { Leader-member } \\
\text { exchange }\end{array}$ & -.23 & 5.17 \\
\hline \multicolumn{3}{|l|}{ Co-worker } \\
\hline Work group cohesion & -.11 & 33.92 \\
\hline Co-worker satisfaction & -.11 & 16.12 \\
\hline \multicolumn{3}{|l|}{ Stress } \\
\hline Role clarity & -.21 & .77 \\
\hline Role overload & .10 & 1.97 \\
\hline Role conflict & .20 & 1.78 \\
\hline Overall stress & .14 & 7.03 \\
\hline \multicolumn{3}{|l|}{ Others } \\
\hline Promotional chances & -.12 & 157.07 \\
\hline Participation & -.11 & 18.47 \\
\hline $\begin{array}{l}\text { Instrumental } \\
\text { communication }\end{array}$ & -.11 & 33.46 \\
\hline \multicolumn{3}{|l|}{ Job Content } \\
\hline $\begin{array}{l}\text { Job scope } \\
\text { Routinisation }\end{array}$ & .09 & $\begin{array}{l}92.08 \\
11.33\end{array}$ \\
\hline Work satisfaction & -.16 & 104.46 \\
\hline Job involvement & -.08 & 48.49 \\
\hline \multicolumn{3}{|l|}{ External Environment } \\
\hline $\begin{array}{l}\text { Alternate job } \\
\text { opportunities }\end{array}$ & .12 & 37.64 \\
\hline $\begin{array}{l}\text { Comparison of } \\
\text { alternatives with } \\
\text { present job }\end{array}$ & .15 & 7.84 \\
\hline
\end{tabular}

Source: (Griffith \& Home, 2000) 
The updated meta-analysis, by and large, replicates the previous study, yielding similar predictive validity for overall job satisfaction and various job attitudes, modestly predicting the turnover. The overall job satisfaction being the best predictor of work satisfaction again showed the highest relationship with the turnover. Pay and pay related factors are modest in their relationship. External environmental factors, like perceived job alternatives modestly predict turnover. Behavioural predictors, lateness, and absenteeism have less predictive accuracy. The performance-turnover relationship is consistent and organisational commitment predicts better overall job satisfaction. These metaanalytical findings carry significant theoretical and practical implications.

\subsection{Professionals and turnover}

A lot of research has been conducted in the area of employee turnover. In fact, it is one of the most studied aspects of organisation behaviour (Mitra, Jenkins \& Gupta, 1992). However, there is a dearth of studies regarding the possible causes of turnover among professionals. Also, most research on professional turnover in general is based on a limited number of professional groups. For example, a meta-analysis that tested the relationship between professional and organisational commitment found no data regarding physicians and lawyers who have been defined as a classic professional group (Gunz\&Gunz, 1994) and relied mostly on data for accountants.

One reason may be the difficulty in accessing this population much of which is dispersed across organisations, offices, and the amount of approvals required at organisational levels. Thus, our knowledge about work behaviour of this interesting professional group is limited. The characteristics of professionals involve membership of professional associations, knowledge base, institutionalised training, intellectual excellence, work autonomy, and code of ethics. Professionals are an exclusive elite group in all societies (Larson, 1978). Their attributes include a high degree of systematic knowledge, strong community orientation, and loyalty (Brown, 1992). A professional requires prolonged specialised training in a body of abstract knowledge, a collectivity or service 
orientation, and a vocational code of behaviour to become part of his / her profession (Jackson, 2010).

Professionals view themselves as employees of special status, resulting among other things, their demand for autonomy (Kerr \& Glinow, 1977). Raelin (2000) identified six characteristics that distinguish them from other types of workers: expertise, autonomy, collegial maintenance of professional standards, commitment to the job as a calling, identification with the profession and fellow professionals and ethics or a felt obligation to render service without concern for self-interest and without becoming emotionally involved with the client. These characteristics indicate that professionals have relatively low levels of attachment to their organisations as compared to their profession. Hence, they switch employment relatively frequently (Raelin, 1991).

Literature has commonly assumed a conflict between the professional and organisational commitments which influence professionals' reactions to their work environment and, consequently, their intentions to withdraw (Aranya, Lachman, \&Amernic, 1982; Martin, 1979; Price \& Mueller, 1981). However, not many significant studies have compared professionals in different occupational settings (Sorensen \& Sorensen, 1974; Kronus, 1976; Tuma \& Grimes, 1981; Aranya et al., 1982).

It is important, therefore, to examine whether the same mechanisms and factors that affect employee turnover in large organisations also operate in the case of professionals. Such research will increase understanding of human-resource management processes and methods in a variety of work settings.

Professionals in India come from a very diverse background; they are generally highly educated, having professional and post graduate degrees in engineering, management, finance, information technology, and so forth. They also undergo a probation period of about one year and an internship during their professional studies. They usually start their career under a senior manager and get an independent charge usually after four to five years of service.

An examination of the antecedents of turnover intentions of professionals employed in well-structured commercial 
organisations deserve an in-depth study because their voluntary turnover carries a cost and reduces the sum-total of organisational knowledge, competence, and critical relationships.

\subsection{Indian context}

India has become the world's third largest economy in terms of purchasing power parity after USA and China. India's gross domestic product (GDP) grew 7.6 percent in $2015-16$, powered by a rebound in farm output and an improvement in electricity generation and mining production in the fourth quarter of the fiscal.

With the world's youngest population median age at 26.2 years (U.S. 36.9, Russia 38.7 and Japan 44.8), Indians are looking to fasttrack their learning experiences and their seniority. Job-hopping appears to be a good way to achieve both. A survey indicated that $78 \%$ young Indians aspired to be in senior executive and/or CEO roles and were very impatient about getting there. A Mercer survey (2014) highlighted that 54\% Indian workers were at flight risk and that figure spiked to $66 \%$ in the 16-24-year age bracket as they just have more opportunities in their buoyant market at present.

Voluntary turnover is a major problem for organisations world over, specifically in Asian countries such as Hong Kong, South Korea, Malaysia, Singapore, and Taiwan (Barnett, 1995; Chang, 1996; Syrett, 1994). Similarly, employee turnover is very prevalent in China (Lachlan, 1996) as well as India with a turnover rate of 26.9\% predicted for 2016 (Group, 2013).

According to global management consulting organisation, (Group, 2013), there will be 49 million more employees who will leave their employers globally in the next five years compared to 2012. This will be because of improvements in the labour market and economic conditions. Also, the employee turnover rates in Asia Pacific will be the highest in comparison to worldwide figures. India will lead the Asia-Pacific region in terms of turnover rates.

Indian business organisations are quite bureaucratic and have multiple levels of authority as compared to their Western counterparts. Similarly, owners and promoters influence executive decision making. Even in case of public sector organisations, 
concerned government ministries influence the decision-making process. Corporate governance standards and ethical behaviour at the top are not always as high as in the West. Indian boards are also not always professionally constituted. Professionals therefore, working in such an environment experience more stress in handling their job responsibilities. However, with the new Company's Act 2013, improvements are on the way. India has a history of strong trade union activities. There are multiple trade unions active in most organisations. These unions are based on political affiliations. Professionals in manufacturing have a responsibility to handle these unions.

India offers several unique features that are very attractive to multinational organisations. A highly skilled and educated workforce, a rapidly growing middle class and an English-speaking populace (Verma, Pichler \& Srinivas, 2005) are some of them. The turnover rates have been quite high in some of the major sectors of the Indian economy. This has led to a discussion about the various retention strategies required to counter the high employee turnover in India as there is a challenge in hiring and retaining talent. Performance losses affect organisations considerably by impacting execution capability, productivity, work team cohesion as well as social good will. Currently a lot of research is being done in the Indian context because of its unique features.

\section{Conceptual and empirical developments}

The conceptual and empirical developments in the area of turnover date back to the time of World War II indicating considerable focus and attention to the area of organisation behaviour and research pertaining to it. Table 2.2 illustrates these developments.

Table 2.2 Significant historical developments

\begin{tabular}{llll}
\hline Researcher & Purpose & Methodology & Relevant Findings \\
\hline Chester & Identified the & Empirical study & Discussed the \\
Bernard & various factors & & economic and social \\
(1938) & responsible for & & factors that help in \\
& individuals to & & attracting \\
& work for & & organisational \\
& organisations. & & members to willingly \\
& & join collaborative
\end{tabular}




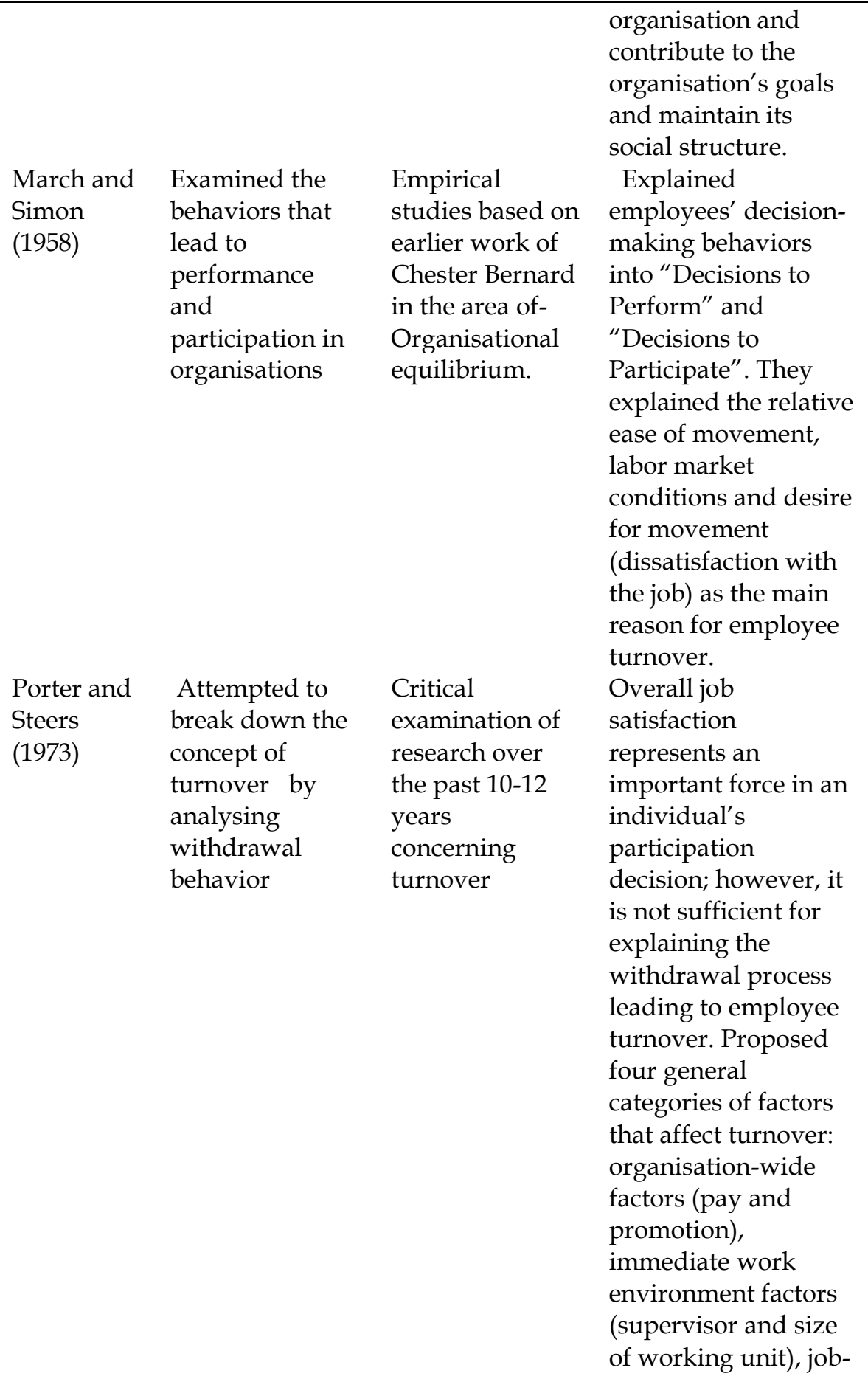




$\begin{array}{lll}\begin{array}{l}\text { Mobley } \\ \text { (1977) }\end{array} & \begin{array}{l}\text { Suggested } \\ \text { several of the } \\ \text { intermediate } \\ \text { steps in the } \\ \text { withdrawal } \\ \text { decision process }\end{array} & \begin{array}{l}\text { Review of } \\ \text { literature an } \\ \text { developmen } \\ \text { a heuristic } \\ \text { model }\end{array} \\ \text { Mobley et } & \begin{array}{l}\text { Attempted to } \\ \text { al. (1979) } \\ \text { clarify and } \\ \text { integrate } \\ \text { constructs of } \\ \text { turnover into a } \\ \text { general model of } \\ \text { the individual } \\ \text { employee } \\ \text { turnover process }\end{array} & \\ & & \\ & & \\ & \end{array}$

related factors (job autonomy and role clarity) and personal factors (age and personality traits). Suggests that thought of quitting is the next step after experiencing dissatisfaction and that intention to leave, following several other steps may be the last step prior to actually quitting Satisfaction, job content, and commitment are consistently and negatively related to turnover. Generally, however, less than $20 \%$ of the variance is explained affecting turnover Intention. Identified four general classes of factors that affect employee turnover; namely, the state of the external economy (unemployment level and inflation), organisational variables (size of unit and job design), individual non-work variables (spouse's career and family responsibility) and individual workrelated variables 


\begin{tabular}{|c|c|c|c|}
\hline $\begin{array}{l}\text { Bluedorn } \\
\text { (1982) }\end{array}$ & $\begin{array}{l}\text { Developed a } \\
\text { unified model of } \\
\text { turnover }\end{array}$ & $\begin{array}{l}\text { A model is } \\
\text { developed by } \\
\text { synthesising } \\
\text { three turnover } \\
\text { models and } \\
\text { tested via path } \\
\text { analysis }\end{array}$ & $\begin{array}{l}\text { Series of structural } \\
\text { and individual } \\
\text { determinants of job } \\
\text { satisfaction; } \\
\text { organisational } \\
\text { commitment; } \\
\text { Strength of } \\
\text { involvement with the } \\
\text { organisation; } \\
\text { Linkages established } \\
\text { between job } \\
\text { satisfaction and } \\
\text { turnover. }\end{array}$ \\
\hline $\begin{array}{l}\text { Cotton and } \\
\text { Tuttle } \\
(1986)\end{array}$ & $\begin{array}{l}\text { Study of } \\
\text { turnover } \\
\text { predictors }\end{array}$ & Meta-Analysis & $\begin{array}{l}\text { Employee turnover } \\
\text { research studies are } \\
\text { reviewed using meta- } \\
\text { analytic techniques. } \\
\text { Almost all variables } \\
\text { (26) relate to } \\
\text { turnover. The } \\
\text { moderating } \\
\text { relationships are } \\
\text { identified. }\end{array}$ \\
\hline $\begin{array}{l}\text { Allen \& } \\
\text { Meyer } \\
(1990)\end{array}$ & $\begin{array}{l}\text { Organisation's } \\
\text { commitment } \\
\text { was looked at as } \\
\text { affective, } \\
\text { normative and } \\
\text { continuance } \\
\text { commitment }\end{array}$ & $\begin{array}{l}\text { Development of } \\
\text { turnover model }\end{array}$ & $\begin{array}{l}\text { The three-component } \\
\text { model of } \\
\text { commitment } \\
\text { developed arguably } \\
\text { dominates } \\
\text { organisational } \\
\text { commitment } \\
\text { research. }\end{array}$ \\
\hline $\begin{array}{l}\text { Tett\& } \\
\text { Meyer } \\
(1993)\end{array}$ & $\begin{array}{l}\text { Job satisfaction } \\
\text { and } \\
\text { organisational } \\
\text { commitment } \\
\text { were compared } \\
\text { as a unique } \\
\text { precursor of } \\
\text { employee } \\
\text { withdrawal }\end{array}$ & $\begin{array}{l}\text { Aggregation of } \\
178 \text { independent } \\
\text { samples from } \\
155 \text { studies }\end{array}$ & $\begin{array}{l}\text { Job Satisfaction, } \\
\text { organisational } \\
\text { commitment and } \\
\text { Intention to quit are } \\
\text { the best predictors of } \\
\text { turnover. Turnover } \\
\text { Intention is the } \\
\text { strongest cognitive } \\
\text { precursor of } \\
\text { turnover. }\end{array}$ \\
\hline
\end{tabular}

(expectations and abilities). Series of structural and individual determinants of job satisfaction organisational Strength of involvement with the anisation; Linkages established between job satisfaction and turnover. research studies are reviewed using metaanalytic techniques. (26) relate to turnover. The relationships are identified.

The three-component model of commitment developed arguably dominates organisational commitment research

ob Satisfaction organisationa commitment and Intention to quit are the best predictors of turnover. Turnover Intention is the strongest cognitive turnover. 


\begin{tabular}{|c|c|c|c|}
\hline $\begin{array}{l}\text { Lee } e t \text { al. } \\
\text { (1996) }\end{array}$ & $\begin{array}{l}\text { Reports on a test } \\
\text { of unfolding } \\
\text { model of } \\
\text { Voluntary } \\
\text { Turnover. }\end{array}$ & $\begin{array}{l}\text { Interviews with } \\
\text { nurses and a } \\
\text { mailed survey } \\
\text { analysed } \\
\text { quantitatively } \\
\text { and } \\
\text { qualitatively }\end{array}$ & $\begin{array}{l}\text { Their research } \\
\text { indicates that } \\
\text { quitting is more } \\
\text { complicated than } \\
\text { traditional turnover } \\
\text { theories implying in } \\
55 \% \text { of the cases, Job } \\
\text { dissatisfaction was } \\
\text { reported, followed by } \\
\text { Job search, the } \\
\text { remaining } 45 \% \text { could } \\
\text { not be easily } \\
\text { explained by } \\
\text { traditional turnover } \\
\text { theories and } \\
\text { introduced a notion } \\
\text { of "Shock" to the } \\
\text { system and four } \\
\text { different decision } \\
\text { pathways. }\end{array}$ \\
\hline $\begin{array}{l}\text { Mitchell } \\
\text { Holtom, } \\
\text { Lee, } \\
\text { Sablynski } \\
\text { \& Erez } \\
(2001)\end{array}$ & $\begin{array}{l}\text { Changed the } \\
\text { direction of } \\
\text { research, asking } \\
\text { why people } \\
\text { stay? Rather } \\
\text { than why they } \\
\text { leave? }\end{array}$ & $\begin{array}{l}\text { Qualitative and } \\
\text { Quantitative } \\
\text { studies } \\
\text { encompassing } \\
\text { banking, } \\
\text { nursing, grocery } \\
\text { store and } \\
\text { accounting staff }\end{array}$ & $\begin{array}{l}\text { Leaving process is } \\
\text { considerably more } \\
\text { complex than } \\
\text { reflected in the } \\
\text { conventional wisdom } \\
\text { Complex theories } \\
\text { leave } 75 \% \text { variance in } \\
\text { turnover } \\
\text { unexplained. } \\
\text { Introduced the idea } \\
\text { of Job } \\
\text { Embeddedness. }\end{array}$ \\
\hline $\begin{array}{l}\text { Mitchell } \\
\text { Holtom \& } \\
\text { Lee (2001) }\end{array}$ & $\begin{array}{l}\text { Introduction of a } \\
\text { new construct to } \\
\text { predict } \\
\text { voluntary } \\
\text { turnover - Job } \\
\text { Embeddedness }\end{array}$ & $\begin{array}{l}\text { Developed a } \\
\text { measure of Job } \\
\text { Embeddedness } \\
\text { with two } \\
\text { samples: } \\
\text { grocery store } \\
\text { and hospital } \\
\text { respondents }\end{array}$ & $\begin{array}{l}\text { Embeddedness } \\
\text { restrains employees } \\
\text { from leaving through } \\
\text { its dimensions } \\
\text { namely Links, Fit and } \\
\text { Sacrifice, both within } \\
\text { and outside the } \\
\text { organisation. }\end{array}$ \\
\hline $\begin{array}{l}\text { Damien } \\
\text { Joseph } \\
\text { (2007) }\end{array}$ & $\begin{array}{l}\text { Introduction of a } \\
\text { comprehensive } \\
\text { model of }\end{array}$ & $\begin{array}{l}\text { Tested among } \\
\text { IT professionals } \\
\text { in Singapore }\end{array}$ & $\begin{array}{l}\text { Encompassed job } \\
\text { related, organisation } \\
\text { related and }\end{array}$ \\
\hline
\end{tabular}


Turnover

Intention contextual factors as well as moderating and mediating factors in the study on the antecedents of turnover intention.

Thus, significant conceptual and empirical developments have taken place in the area of turnover. Though a lot of research has been done in the area of employee turnover in terms of identifying and isolating the various factors that are significant, this area continues to attract researchers because of the enormous costs involved in identifying the right quality of talent, investing in their training and development and making them productive in their jobs.

\section{Theories of turnover}

There have been many theories regarding why employees leave their organisations voluntarily.

Organisational Equilibrium Theory: The theory of March \& Simon (1958) is perhaps the most significant among the various theories on turnover. According to this theory, turnover is the result of individual contributions exceeding organisational inducements. This is influenced by the employee's dissatisfaction resulting in a desire to move and employment opportunities available due to macro level factors of economy. Most of the subsequent development in the area of turnover is attributed to March and Simon's model by expanding on it or theorising decisions to quit (Cohen \& Hudecek, 1993; Hom et al., 1992; Porter \& Steers, 1973; Porter et al., 1976; Price, 1977).

Met expectations theory: Met and unmet expectations are seen as key reasons behind turnover decisions. 'Met expectations' are the actual positive and negative experiences encountered vs. expectations like rewards, advancement, and relations with peers and supervisors (Porters \& Steers, 1973). The dissatisfaction because of these failed expectations is usually the cause of the turnover. 
Linkage Model: There is a series of intermediate links that exist between job dissatisfaction and turnover like thoughts of leaving, evaluating alternate jobs and intentions to quit. When a suitable alternate job that is more attractive is found, the individual develops an intention to quit and he leaves (Mobley, 1977).

Unfolding Model of Turnover: This model proposed by Lee and Mitchell (1994) highlights the paths people take when they quit. Turnover process is often triggered by a shock or certain events.

Job Embeddedness Theory: This theory is unique as it suggests why employees stay and not quit. It suggests that employees get enmeshed in a web that prevents them from quitting. These could be because of the links that they have with other people or activities, being settled in their jobs and communities, and sacrifices they have to make if they leave (Mitchell et al., 2001). Unlike other theories, non-work factors were also included that affect an individual's reason not to leave.

\section{Models of turnover}

The classic turnover model based on job attitude is constructed on the basis of psychological processes. It puts research focus on the mutual relations of employees' turnover behaviour, including job satisfaction, organisational commitment and other variables as mediator variables, generating various representative organisational models in different periods. These model variables were increasingly generated and their relationships among them gradually became complicated (Griffeth et al., 2000; Lee et al., 2004). The models include the Process model of Price (1977), Media Chain Model of Mobley (1979) and Steers and Mowday (1981).

\subsection{Attitudinal factors}

Griffith et al. (2000) conducted a meta-analysis of research on turnover research papers. The result of the meta-analysis resulted in eleven demographic predictors, sixteen work and organisation related factors like pay, satisfaction with supervisor and co-workers and so forth. Six variables pertaining to job and external environment, and three behavioural predictors were also identified. 
A general research model and an analysing route for traditional attitude research model emerged from this review are presented in the following exhibit:

Exhibit 2.2 Traditional attitude model of voluntary turnover

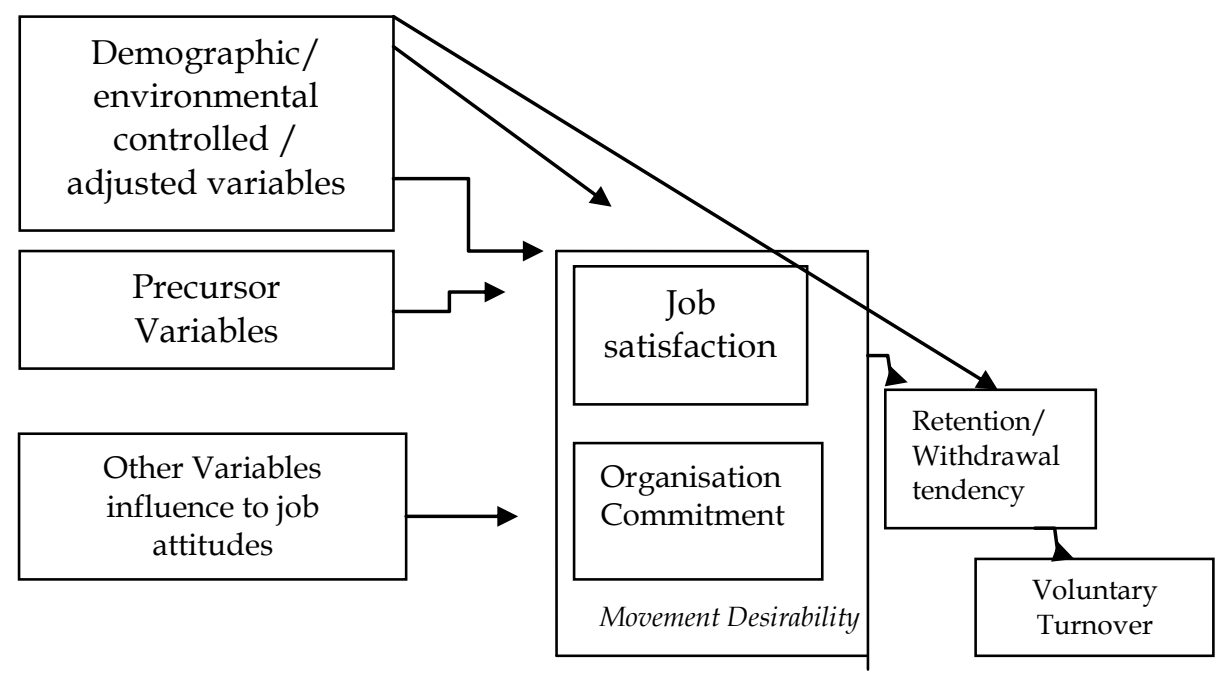

Source: Griffeth, Hom, \& Gaertner, S. (2000). A meta-analysis of antecedents and correlates of employee turnover: Update, moderator tests, and research implications for the next millennium.

However, Griffeth, Hom and Gaertner, (2000) and Hom and Griffeth (1995), report that variance accounted by these attitudinal variables is relatively low, comprising about $15-25 \%$ of the variance in voluntary turnover with the individual variables rarely accounting for more than $10 \%$ of the variance. Thus, quite a few meaningful areas still need to be researched.

\subsection{Attitudes to organisational non-work factors}

Empirical findings suggest that many factors that are off the job are important for predicting turnover intentions. Non-work influences like family attachments, conflict between work and family roles, having children and spouse at home (Lee \& Maurer, 1981) are better predictors of leaving a job than organisational commitment.

Thus, there are some forces or factors that impel an employee to quit and search for alternative jobs while there are others that induce him to stay. The situation is best expressed by Kurt Lewin's 
famous model of dynamic equilibrium in which all employees are in a given state of organisational flux and subjected to opposite forces. When the forces that impel him to quit are stronger compared to organisational job-satisfaction-commitment-cultural factors, the employee turnover takes place. This is also known as Push and Pull theory of turnover.

Inter-role conflict: In the work-family conflict literature (Cohen, 1997; Netermeyer, Boles \& McMurrian, 1996), it is concluded that job switches hinge more on interfering factors including but not restricted to factors such as extra work commitments. The same was propounded earlier by March and Simon (1958); the greater demands at the workplace make it impossible to fulfil expectations in other social groups and this in turn increases the desirability of movement.

Job avoidance: According to Krausz, Koslowasky and Eiser (1985), unhappy employees who miss work or arrive late are more prone to depart. Hence, they assert that job satisfaction reduces job avoidance and job avoidance increases withdrawal cognitions.

\subsection{Performance-turnover relationship}

Allen and Griffeth (1999), Mitchell (2001), Lee (1999) and Huselid (1995), researched on the employee's performance level relationship to their voluntary turnover. The research is summarised as consisting of three routes that when adopted will influence job satisfaction (movement desirability) and organisational commitments. Secondly, performance level will influence turnover behaviour through movement in labour markets with perceived mobility easiness.

Hausknecht (2008) listed the 12 major retention factors that have been published in literature over the last 60 years from a survey of 24,829 employees in the leisure and hospitality industry of the US which help explain why employees stay or quit given in Table 2.3. 
Table 2.3 Description of retention factors or turnover antecedents

\begin{tabular}{|c|c|}
\hline Retention factor & Definition \\
\hline $\begin{array}{ll}\text { 1. } & \text { Job } \\
\text { satisfaction }\end{array}$ & The degree to which individuals like their jobs \\
\hline $\begin{array}{l}\text { 2. Extrinsic } \\
\text { rewards }\end{array}$ & $\begin{array}{l}\text { The amount of pay, benefits, or equivalents in return } \\
\text { for service. }\end{array}$ \\
\hline $\begin{array}{l}\text { 3. Constitutio } \\
\mathrm{n} \\
\text { attachments }\end{array}$ & $\begin{array}{l}\text { The degree of attachments to individuals associated } \\
\text { with the organisation such as supervisor, co-workers, } \\
\text { or customers }\end{array}$ \\
\hline $\begin{array}{l}\text { 4. Organisatio } \\
\text { nal } \\
\text { commitmen } \\
\text { ts }\end{array}$ & $\begin{array}{l}\text { The degree to which individuals identify with and are } \\
\text { involved in the organisation. }\end{array}$ \\
\hline $\begin{array}{l}\text { 5. Organisatio } \\
\text { nal }\end{array}$ & $\begin{array}{l}\text { The degree to which the organisation is perceived to be } \\
\text { reputable and well regarded. }\end{array}$ \\
\hline 6. Prestige & \\
\hline $\begin{array}{l}\text { 7. Lack of } \\
\text { alternatives }\end{array}$ & $\begin{array}{l}\text { Beliefs about the unavailability of jobs outside the } \\
\text { organisation. }\end{array}$ \\
\hline 8. Invest & $\begin{array}{l}\text { Perceptions about the length of service to the } \\
\text { organisation. }\end{array}$ \\
\hline $\begin{array}{l}\text { 9. Advanceme } \\
\text { ntopportuni } \\
\text { ties }\end{array}$ & $\begin{array}{l}\text { The amount of potential for movement to higher levels } \\
\text { within the organisation. }\end{array}$ \\
\hline 10. Location & mity of the workplace relative to one's home. \\
\hline $\begin{array}{l}\text { 11. Organ } \\
n \text { justi }\end{array}$ & $\begin{array}{l}\text { Perceptions about the fairness of reward allocations, } \\
\text { policies and procedures and interpersonal treatment. }\end{array}$ \\
\hline $\begin{array}{l}\text { 12. Flexible } \\
\text { work }\end{array}$ & The nature of the work schedule or hours \\
\hline $\begin{array}{l}\text { 13. Non-work } \\
\text { influence }\end{array}$ & $\begin{array}{l}\text { The existence of responsibilities and commitments } \\
\text { outside of the organisation. }\end{array}$ \\
\hline
\end{tabular}

Source: Hausknecht, Rodda, \& Howard (2009). Targeted employee retention: Performance-based and job-related differences in reported reasons for staying.

\subsection{Job embeddedness model}

The job embedded theory proposed by Holtom, Lee, Sablynski and Erez (2001) proposed that embedded figures are immersed in their background and are hard to separate. People have perceptual life spaces in which their lives are represented and connected. These 
connections can be less or more and close or distant. People can get stuck into these web-like connections.

Hulin's (1991) earlier work focussed on the predictors of organisational attachment. But what was not explained by earlier researchers was why people leave in spite of an attachment with the current job without having searched for job alternatives. Mitchell et al. (2001) tried to explain the above paradoxes through their theory of job embeddedness (also known as on-the-job and off-the-job coupling) through the dimensions of Links, Fit and Sacrifice.

Job embeddedness is broader than any of the constructs discussed in literature. It includes an assessment of some factors, both on and off the job that are not measured elsewhere. Its dimensions are less affective in nature. Link is clearly non-affective and faith and sacrifice are partially affective. Some authors claim that in the construct level, job embeddedness is conceptually unique in turnover literature. The job embeddedness model is given in the exhibit below:

Exhibit 2.3 Job Embeddedness Model

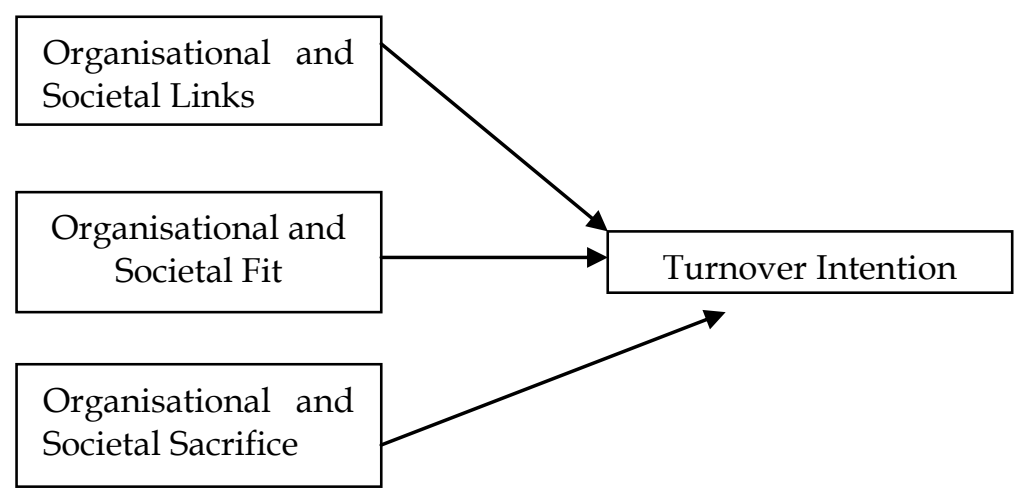

Source: Adapted from Mitchell, T. R., \& Lee, T. W. (2001). The unfolding model of voluntary turnover and job embeddedness: Foundations for a comprehensive theory of attachment.

\section{Research on professionals and turnover}

In a meta-study of 30 studies of the IT industry and study of antecedents of turnover intentions of IT professional, Joseph et al. 
(2007), reported 43 antecedents of turnover intentions and tested a model by analytic structural equation modeling.

Ovadje (2010) explored turnover among middle managers in a nonwestern culture focussing on the drivers of turnover intention among middle managers in Nigeria. The study variables were turnover intention (dependent) and perceived organisational support, management style organisational commitment, satisfaction with pay and benefits, and turnover culture as independent variables.

Faculty of business schools are professionals in their own rights although they face different types of pressures. In an empirical study of Indian business schools in India, Azmi and Sharma (2012) explored the relationship between retention factors, organisational commitment and actual turnover. Their research enquired about factors which would ensure organisational commitment of teachers and the relationship existing between organisational commitment and the actual turnover.

Chang et al. (2008), in a study of professionals with a degree of $\mathrm{PhD}$ in a Korean electronics firm, focussed on the role of three pre-entry characteristics: cognitive style, work values and career orientation as significant predictors of turnover intentions.

Hee and Ling (2011) in a research on strategies for reducing employee turnover and increasing retention rates of quantity surveyors in construction management explored the job and job holder's characteristics that significantly affected the retention of quantity surveyors in their profession.

This review of literature and research has highlighted the development of ideas, theories, and models in a systematic manner in the field of voluntary turnover and the antecedents of turnover intentions, in particular, focussing on the professionals.

\section{Research gap}

From a review of extant literature, the following gaps can be identified:

Many studies concerning employee retention have been conducted mainly in the U.S and Europe to determine the main factors that 
contribute to their satisfaction and motivation to exist. Replication of such studies in other regions is highly justifiable. Limited studies have been conducted on professionals from developing or lessdeveloped countries (Tetty, 2006).

Although some studies exist in the Indian context, there have not been extensive studies on professionals with specific reference to manufacturing and services organisations. Literature survey has brought out that the samples of existing research studies on turnover intentions in India have focussed on nurses, BPO, and IT staff (Bjorkman \& Budhwar, 2007; Budhwar\& Varma, 2010).

The characteristics of professionals according to research (Raelin, 2000; Glinow, 1996) indicate that professionals are highly qualified and have relatively low levels of attachment to their organisations and more to their professions and switch employment relatively frequently (Raelin, 1991). Therefore, further research is justified on employee's subgroups of professionals.

The field of voluntary employee turnover has received much attention over the past decades. Research has centered on both conceptual developments (Lee \& Mitchell, 1994; Steel et al., 2002) and empirical analyses of various turnover antecedents (Griffeth et al., 2000). However, studies have primarily addressed individuallevel predictors of turnover whereas the examination of organisational determinants has been mostly neglected (Shaw et al., 1998).

Though job satisfaction is one of the most researched topics in the field of organisational behaviour (Spector 1997), job satisfaction of knowledge workers is one area that further needs to be researched upon (Narang \& Dwivedi, 2010).

Although the proposed negative relationship between organisational commitment and turnover has received wide empirical support (Mael\&Ashforth 1995; Wan-Huggins et al., 1998; Riketta 2005), it is less clear which organisation-level factors will influence the turnover in general and the commitment-turnover relationship for professionals. 


\section{Conclusion}

In spite of numerous studies and meta-researches on factors affecting flight risk of professionals, this area remains one of most researched areas in organisation behaviour studies due to the implications it has on curtailing the flight risk as well as the tremendous costs involved in hiring, training and on-boarding professionals. Professionals can impact the competitive advantage, top and bottom line and thus there needs to be a constant vigil on them and algorithms and models that can successfully predict their flight risk will be most sought after by organisations.

\section{References}

Abelson, M. A., \& Baysinger, B. D. (1984). Optimal and dysfunctional turnover: Toward an organizational level model. Academy of Management Review, 9(2), 331-341. doi:10.5465/amr.1984.4277675

Ajzen, I., \& Fishbein, M. (1980). Understanding attitudes and predicting social behavior. Englewood Cliffs, NJ: Prentice-Hall.

Allen, D. G., \& Griffeth, R. W. (1999). Job performance and turnover: A review and integrative multi-route model. Human Resource Management Review, 9(4), 525-548. doi:10.1016/s1053-4822(99)00032-7

Allen, D. G., Bryant, P. C., \& Verdman, J. M. (2010). Retaining talent: Replacing misconceptions with evidence-based strategies. Academy of Management Perspectives, 24(2), 48-64. doi:10.5465/amp.2010.51827775

Arthur, J.B. (1994). Effects of human resource systems on manufacturing performance and turnover. The Academy of Manufacturing Performance, 37(3), 670-687.

Aranya, N., Lachman, R., \& Amernic, J. (1982). Accountants' job satisfaction: A path analysis. Accounting, Organizations and Society, 7(3), 201-215. doi:10.1016/0361-3682(82)90001-0

Azmi, F. T., \& Sharma, M. (2012). Job related dimensions and faculty members' satisfaction at Indian business schools: An empirical study. International Journal of Management and Business Research, 2(1), 23-40.

Barnett, R. (1995). Flexible benefits: Communication is the key. Benefits and Compensation International, 24(6), 25-28.

Bauer, T. N., Bodner, T., Erdogan, B., Truxillo, D. M., \& Tucker, J. S. (2007). Newcomer adjustment during organizational socialization: A metaanalytic review of antecedents, outcomes, and methods. Journal of Applied Psychology, 92(3), 707-721. doi:10.1037/0021-9010.92.3.707

Björkman, I., \& Budhwar, P. (2007). When in Rome ...? Employee Relations, 29(6), 595-610. doi:10.1108/01425450710826104 
Brown, J. (1992). The definition of a profession: The authority of metaphor. The History of Intelligence Testing, 1890-1930. Princeton, NJ: Princeton University Press, 19.

Budhwar, P., \& Varma, A. (2010). Guest editors' introduction: Emerging patterns of HRM in the new Indian economic environment. Human Resource Management, 49(3), 345-351. doi:10.1002/hrm.20364

Chang, H. (1996). In Singapore, the dreams are getting bigger. Business Week. September.

Chang, J. Y., Choi, J. N., \& Kim, M. U. (2008). Turnover of highly educated R\&D professionals: The role of pre-entry cognitive style, work values and career orientation. Journal of Occupational and Organizational Psychology, 81(2), 299-317. doi:10.1348/096317907×204453

Cohen, A., \& Hudecek, N. (1993). Organizational commitment-turnover relationship across occupational groups: A meta-analysis. Group and Organization Management, 18(2), 188-213. doi:10.1177/ 1059601193182004. Factors affecting turnover intention of nonmanagerial clerical staff

Cohen, A. (1997). Non-work influences on withdrawal cognitions: An empirical examination of an overlooked issue. Human Relations,50(12), 1511-1536. doi:10.1177/001872679705001203

Cohen, S. G., \& Bailey, D. E. (1997). What makes teams work: Group effectiveness research from the shop floor to the executive suite. Journal of Management, 23, 239-290.

Cotton, J. L., \& Tuttle, J. M. (1986). Employee turnover: A meta-analysis and review with implications for research. Academy of Management Review, 11(1), 55-70. doi:10.5465/amr.1986.4282625

Firth, L., Mellor, D. J., Moore, K. A., \& Loquet, C. (2004). How can managers reduce employee intention to quit? Journal of Managerial Psychology, 19(2), 170-187. doi:10.1108/02683940410526127

Griffeth, R. W., Hom, P. W., \& Gaertner, S. (2000). A meta-analysis of antecedents and correlates of employee turnover: Update, moderator tests, and research implications for the next millennium. Journal of Management, 26(3), 463-488. doi:10.1177/014920630002600305

Gunz, H. P., \&Gunz. (1994). Professional/organizational commitment and job satisfaction for employed lawyers. Human Relations, 47(7), 801-828. doi:10.1177/001872679404700703

Halaby, C. N. (1986). Worker attachment and workplace authority. American Sociological Review, 51(5), 634. doi:10.2307/2095489

Hausknecht, J. P., Rodda, J., \& Howard, M. J. (2009). Targeted employee retention: Performance-based and job-related differences in reported reasons for staying. Human Resource Management, 48(2), 269-288. doi:10.1002/hrm.20279

Hay Group. (2013). Preparing for take-off. Study Report. India. 
Holtom, B. C., Mitchell, T. R., Lee, T. W., \&Inderrieden, E. J. (2005). Shocks as causes of turnover: What they are and how organizations can manage them. Human Resource Management, 44(3), 337-352. doi:10.1002/hrm.20074

Hom, P. W., \& Griffeth, R. W. (1995). Employee turnover. Cincinatti, OH: South-Western College.

Hom, P. W., Caranikas-Walker, F., Prussia, G. E., \& Griffeth, R. W. (1992). A meta-analytical structural equations analysis of a model of employee turnover. Journal of Applied Psychology, 77(6), 890-909. doi:10.1037/0021-9010.77.6.890

Hulin, C. L., Roznowski, M., \& Hachiya, D. (1985). Alternative opportunities and withdrawal decisions: Empirical and theoretical discrepancies and an integration. Psychological Bulletin, 97(2), 233-250. doi:10.1037/ /0033-2909.97.2.233

Hulin, C. L. (1991). Adaptation, persistence, and commitment in organizations. In M. D. Dunnette \& L.M. Hough (Eds.), Handbook of industrial and organizational psychology (2nd ed.), Vol. 2, pp. 445-506. Palo Alto, CA: Consulting Psychologists Press.

Huselid, M. A. (1995). The impact of human resource management practices on turnover, productivity, and corporate financial performance. Academy of Management Journal, 38(3), 635-673. doi:10.2307/256741

Igbaria, M., \& Greenhaus, J. H. (1992). Determinants of MIS employees' turnover intentions: A structural equation model. Communications of the ACM, 35(2), 34-49. doi:10.1145/129630.129631

Jackson, J. A. (2010). Professions and professionalization (Vol. 3). Sociological Studies). Cambridge: Cambridge University Press.

Joseph, D., Kok-Yee, N., Koh, C., \& Soon, A. (2007). Turnover of information technology professionals: A narrative review, metaanalytic structural equation modeling, and model development. MIS Quarterly, 31(3), 547-577.

Kerr, S., Glinow, M. A., \& Schriesheim, J. (1977). Issues in the study of "professionals" in organizations: The case of scientists and engineers. Organizational Behavior and Human Performance, 18(2), 329-345. doi:10.1016/0030-5073(77)90034-4

Krausz, M., Koslowsky, M., \& Eiser, A. (1998). Distal and proximal influences on turnover intentions and satisfaction: Support for a withdrawal progression theory. Journal of Vocational Behavior, 52(1), 5971. doi:10.1006/jvbe.1996.1565

Kronus, C. L. (1976). Occupational versus organizational Influences on reference group identification: The case of pharmacy. Work and Occupations,3(3), 303-330. doi:10.1177/003803857600300303 
Larson, M. S. (1978). The rise of professionalism: A sociological analysis. Berkeley, CA: University of California.

Lee, T. W., \& Maurer, S. D. (1991). The effects of family structure on organizational commitment, intention to leave and voluntary turnover. Journal of Managerial Issues, 11, 493-513.

Lee, T. W., \& Mitchell, T. R. (1994). An alternative approach: The unfolding model of voluntary employee turnover. Academy of Management Review, 19, 51-89.

Lepak, D. P., \& Snell, S. A. (2002). Examining the human resource architecture: The relationship among human capital, employment, and human resource configurations. Journal of Management, 28(4), 517543.

MacLachlan, R. (1996). Job-Hopping or 'industrial espionage'. Personnel Management, 2(14), 15-16.

Mael, F. A., \& Ashforth, B. E. (1995). Loyal from day one: Biodata, organizational identification, and turnover among newcomers. Personnel Psychology, 48(2), 309-333. doi:10.1111/j.17446570.1995.tb01759.x.

Martin Jr., T.N. (1979). A contextual model of employee turnover intentions. Academy of Management Journal, 22(2), 313-324

March, J. G., \& Simon, H. A. (1958). Organizations. New York: Wiley.

Mcevoy, G. M., \& Cascio, W. F. (1985). Strategies for reducing employee turnover: A meta-analysis. Journal of Applied Psychology, 70(2), 342-353. doi:10.1037/0021-9010.70.2.342

Mitchell, T. R., \& Lee, T. W. (2001). The unfolding model of voluntary turnover and job embeddedness: Foundations for a comprehensive theory of attachment. Research in Organizational Behavior, 23, 189-246. doi:10.1016/s0191-3085(01)23006-8

Mitra, A., Jenkins, G. D., \& Gupta, N. (1992). A meta-analytic review of the relationship between absence and turnover. Journal of Applied Psychology, 77(6), 879-889. doi:10.1037/0021-9010.77.6.879

Mobley, W. H. (1977). Intermediate linkages in the relationship between job satisfaction and employee turnover. Journal of Applied Psychology, 62(2), 237-240. doi:10.1037/0021-9010.62.2.237

Mobley, W. H. (1982). Employee turnover, causes, consequences, and control. Reading, MA: Addison-Wesley.

Mobley, W. H. (1982). Some unanswered questions in turnover and withdrawal research. The Academy of Management Review, 7(1), 111. doi:10.2307/257255

Muchinsky, P. M., \& Morrow, P. C. (1980). A multidisciplinary model of voluntary employee turnover. Journal of Vocational Behavior, 17(3), 263290. doi:10.1016/0001-8791(80)90022-6 
Mueller, C. W., Iverson, R. D., \& Price, J. L. (1999). The effects of group racial composition on job satisfaction, organizational commitment, and career commitment. Work and Occupation, 26, 187-219.

Narang, R., \& Dwivedi, A. (2010). Managing the job satisfaction of knowledge workers: An empirical investigation. Asia Pacific Journal of Business and Management, 1(1), 1-14.

Netemeyer, R. G., Boles, J. S., \&Mcmurrian, R. (1996). Development and validation of work-family conflict and family-work conflict scales. Journal of Applied Psychology, 81(4), 400-410. doi:10.1037/00219010.81.4.400

Ovadje, F. (2010). Exploring turnover among middle managers in a nonwestern context. International Journal of Management Studies, 10(2), 6480.

Pfeiffer, W., \& Ballew, A. (1991). Theory X-theory Y, theories and models. Applied Behaviour Science, 1, 273.

Phillips, J. M. (1998). Effects of realistic job previews on multiple organizational outcomes: A meta-analysis. Academy of Management Journal, 41(6), 673-690. doi:10.2307/256964

Porter, L. W., \& Steers, R. M. (1973). Organizational, work, and personal factors in employee turnover and absenteeism. Psychological Bulletin, 80(2), 151-176. doi:10.1037/h0034829

Price, J. L., \& Mueller, C. W. (1981). A causal model of turnover for nurses. Academy of Management Journal, 24(3), 543-565. doi:10.2307/255574

Price, J. L., \& Mueller, C. W. (1986). Absenteeism and turnover of hospital employees. Greenwich, CT: JAI Press.

Price, J. L. (1977). The study of turnover. Ames: Iowa State University Press.

Raelin, J. A. (1991). The clash of cultures: Managers managing professionals. Boston, MA: Harvard Business School Press.

Raelin, J. A. (1991). The effect of graduate management action learning environments on public reflectiveness in managerial practice. Management Research News, 14(7/8/9), 43-48. doi:10.1108/eb028154

Raelin, J. A. (2000). Work-based learning: The new frontier of management development. Upper Saddle River, NJ: Prentice Hall.

Riketta, M. (2005). Organizational identification: A meta-analysis. Journal of Vocational Behavior, 66(2), 358-384. doi:10.1016/j.jvb.2004.05.005

Shaw, J. D., Delery, J. E., Jenkins, G. D., \& Gupta, N. (1998). An organization-level analysis of voluntary and involuntary turnover. Academy of Management Journal, 41(5), 511-525. doi:10.2307/256939

Shore, L. M., \& Martin, H. J. (1989). Job satisfaction and organizational commitment in relation to work performance and turnover intentions. Human Relations, 42(7), 625-638. doi:10.1177/001872678904200705 
Sorensen, J. E., \& Sorensen, T. L. (1974). The conflict of professionals in bureaucratic organizations. Administrative Science Quarterly,19(1), 98. doi:10.2307/2391790

Spector, P. E. (1997). Job satisfaction: Application, assessment, causes and consequences. Thousand Oaks, Ca: Sage.

Steers, R. M., \&Mowday, R. T. (1981). Employee turnover and post decision accommodation processes. In L.L. Cummngs and B. Staw (eds.) Research in organizational behavior, (pp. 235-281). Greenwich, CT: JAI Press.

Syrett, M. (1994). Through thick and thin. Asian Business, 30 (12), 26-30.

Tetty, W. (2006). Staff retention in African universities: Elements of a sustainable strategy. World Bank: Washington DC.

Thompson, K. R., \& Terpening. (1983). Job-type variations and antecedents to intention to leave: A content approach to turnover. Human Relations, 36(7), 655-681. doi:10.1177/001872678303600705

Tuma, N. B., \& Grimes, A. J. (1981). A comparison of models of role orientations of professionals in a research- oriented university. Administrative Science Quarterly, 26(2), 187-206. doi:10.2307/2392468

Varma, A., Pichler, S., \& Srinivas, E. S. (2005). The role of interpersonal affect in performance appraisal: Evidence from two samples - the US and India. The International Journal of Human Resource Management,16(11), 2029-2044. doi:10.1080/09585190500314904

Wan-Huggins, V. N., Riordan, C. M., \& Griffeth, R. W. (1998). The development and longitudinal test of a model of organizational identification. Journal of Applied Social Psychology, 28(8), 724-749. doi:10.1111/j.1559-1816.1998.tb01728.x 